\title{
Development Prospects of Tourist Passenger Shipping in the Polish Part of the Vistula Lagoon
}

\author{
Krystian Puzdrakiewicz *(D) and Marcin Połom *(D) \\ Division of Regional Development, Faculty of Oceanography and Geography, University of Gdańsk, \\ 80-309 Gdańsk, Poland \\ * Correspondence: krystian.puzdrakiewicz@ug.edu.pl (K.P.); marcin.polom@ug.edu.pl (M.P.)
}

Citation: Puzdrakiewicz, K.; Połom, M. Development Prospects of Tourist Passenger Shipping in the Polish Part of the Vistula Lagoon. Sustainability 2021, 13, 5343. https://doi.org/ $10.3390 /$ su13105343

Academic Editors:

Madeleine Granvik and Walter Leal Filho

Received: 11 March 2021

Accepted: 4 May 2021

Published: 11 May 2021

Publisher's Note: MDPI stays neutral with regard to jurisdictional claims in published maps and institutional affiliations.

Copyright: (c) 2021 by the authors. Licensee MDPI, Basel, Switzerland. This article is an open access article distributed under the terms and conditions of the Creative Commons Attribution (CC BY) license (https:// creativecommons.org/licenses/by/ $4.0 /)$.
Abstract: The Vistula Lagoon is a cross-border area with high natural values and a developing market of tourist services. Passenger shipping is an important part of local tourism, but ship owners are insufficiently involved in planning processes and their views on creating shipping development are underrepresented. The article aims to compare the vision of the development of passenger shipping in the Polish part of the Vistula Lagoon between local governments creating the spatial policy and ship owners offering transport services. We have made an attempt to verify the development prospects. The collation of these visions was based primarily on the qualitative analysis of the content of planning and strategic documents (desk research method) and a survey conducted among all six ship owners. Thanks to the comparative analysis, it was possible to show similarities and differences and to indicate recommendations. The paper presents review of the available literature on the subject, thanks to which the research area was identified as unique in Europe. On the one hand, it is a valuable natural area, which is an important tourist destination, on the other hand, there are organizational and infrastructural limitations in meeting the needs of tourists. Then, field research was conducted, unpublished materials were collected, and surveys were conducted with the operators of passenger ships operating in the Vistula Lagoon. The performed analyses allowed for the formulation of conclusions and recommendations. Similarities in the directions of promoting tourism in the region, improving the quality of infrastructure, eliminating obstacles in international traffic and discrepancies in the co-financing of ship owners' activities by local governments, shaping the future transport offer or the construction of the Vistula Spit canal are identified. Economic calculation, particularly vital for the private sector (ship owners), is an important criterion for verifying the assumed goals.

Keywords: passenger shipping; tourism; ship owners; local development; Vistula Lagoon

\section{Introduction}

The coastal zone has a natural predisposition to concentrate activities regarding tourism and water transport. Their scale largely depends on physical-geographical, socioeconomic and legal conditions (mainly the environmental law and the possibility of crossing international borders). Lagoons are a specific form of surface waters whose high natural values contribute to the commercialization of their use in the form of tourism. The Vistula Lagoon has been classified as a rather capitalized lagoon among water reservoirs located in European countries [1,2]. On a national scale, it is a region of above-average importance for tourism (mainly sightseeing and recreation). Cities and other units of the administrative division in which tourist activity takes place also financially benefit from it. However, there is a great responsibility on the part of local and regional authorities for building an environment conducive to the functioning of the tourism industry and the related entities. Therefore, it is a bilateral relationship in which recognizing interests of both parties is crucial for achieving satisfactory cooperation based on synergy [3].

Tourism is a factor initiating the socio-economic development of cross-border regions and it stimulates the strengthening of international cooperation [4-7]. The current 
geopolitical situation in the Vistula Lagoon region is not conducive to the development of tourism and international transport, but local activities aim at supporting the activities of the tourism industry. Creating a policy conducive to development is both the responsibility and the interest of local governments. Developing an appropriate strategy to achieve the intended goals should include multi-criteria analyses taking into account the widest possible group of stakeholders. The multitude of administrative borders at different levels hinders an efficient and coherent management in the functional area of the Vistula Lagoon. To illustrate these difficulties, it suffices to mention that the waters of the Vistula Lagoon are divided between two countries, and in the Polish part the key divisions concern: seven municipalities, four counties, two regional self-administrations (voivodeship), one Maritime Office, two Regional Water Management Boards and two Regional Inspectorates for Environmental Protection [8,9].

In the Polish conditions, Kizielewicz [9] conducted research on passenger shipping and relations between port authorities and ship owners. However, that research concerned cruise ships and the largest ports of strategic importance for the national economy, so the scale of this activity goes far beyond the currently operating navigation on the Vistula Lagoon. In the past, workshops were held to identify problems and learn about local communities' opinions regarding the analyzed lagoon. They were attended, among others, by representatives of the authorities, local residents, fishermen, hotel and restaurant owners, but they did not involve transport operators as representatives of the tourism industry $[8,10]$. Thus, in the literature on the Vistula Lagoon, a significant lack of knowledge is identified in the form of recognizing the needs, operation and development plans of ship owners offering passenger transport services. They are the key economic entities whose activity significantly affects the overall tourist attractiveness of the region.

In view of the above, the aim of this article is to compare the vision of the development of passenger shipping in the Polish part of the Vistula Lagoon between local governments creating the spatial policy and ship owners offering transport services. While recognizing the research gap regarding the potential of the Vistula Lagoon for the development of passenger shipping, research questions were identified:

(1) To what are extent the needs and development plans of ship owners are taken into account in official visions for the development of local governments?

(2) What issues concerning the development of sea tourism, in particular passenger ferry shipping, are included in the planning and strategic documents of local governments?

(3) Do the planning and strategic documents of local governments and the owners of passenger ships see opportunities in the field of the development of passenger shipping in the Vistula Lagoon after the construction of the Vistula Spit canal?

The structure of the article corresponds to the conducted research procedure. The subsequent section details the characteristics of the analyzed area and describes the methods and data sources. The result part presents the current state of passenger navigation in the Vistula Lagoon, then the development vision of local and regional self-governments expressed in planning and strategic documents, as well as the perspective of the development of transport activities from the ship owners' point of view. The paper is completed with a discussion of the results of the development visions and with conclusions.

\section{Material and Methods}

\subsection{Study Area of the Vistula Lagoon}

The Vistula Lagoon (in the Russian part it is called the Kaliningrad Lagoon) is one of the four lagoons located in the Baltic Sea basin. It is located in its southeastern part (Figure 1). The Vistula Lagoon is separated from the Bay of Gdańsk by the Vistula Spit and has one direct connection with the waters of the open sea via the Baltiysk Strait on the Russian side. Formally, the entire lagoon is considered as marine internal waters. This is a cross-border area of which $56 \%$ belongs to the Russian Federation (Kaliningrad Oblast) and $44 \%$ to the Republic of Poland. The land and sea border, constituting the external border of the European Union and the Schengen Zone, is of paramount importance in the geopolitical 
situation of the region. Currently, there is no free movement between countries here, which is crucial for various types of tourism. After the collapse of the Soviet Union, the border was opened for individual trips in 1990. Duty-free cruises between Tricity and Baltiysk were popular among Polish tourists. Introducing local border traffic in the border zone in 2012 was a vital impulse in the development of tourism, but it did not include sea border crossings [11-15]. Emphasis on developing cross-border cooperation, including water tourism, was the subject of programs of Russia-EU cooperation $[7,15,16]$. Nevertheless, since 2009, the access of Polish vessels to the waters of the Vistula Lagoon within Russia has been hampered by the necessity to notify of the intention to enter Russian waters at least 14 days in advance, with a possibility of refusal at any time. There is also a ban on ships belonging to third countries [14]. Currently, visa traffic is allowed. Restrictions of this type have a negative impact on the functioning of the tourism industry [11,17], which is not properly developed in the area of the Vistula Lagoon [18]. There is a clear dominance of domestic tourists (over 90\%) in all registered overnight stays [5]. For most tourists the destinations include towns located on the Vistula Spit, due to access to coastal beaches. Waters of the Vistula Lagoon are subject to strong eutrophication, which is not conducive to their full use for recreation. In general, the area adjacent to the lagoon is poorly invested in; it has mostly low population density and experienced many socio-economic problems in the past, such as high unemployment or insufficiently developed infrastructure $[7,19,20]$. The main settlement centers of the region have seaports, with the most important being Kalingrad, Baltiysk, Swetly on the Russian side, and Elblag, Krynica Morska and Frombork on the Polish side. In addition, there are two large ports in Gdynia and Gdańsk on the Bay of Gdańsk, as part of the Tricity urban complex.

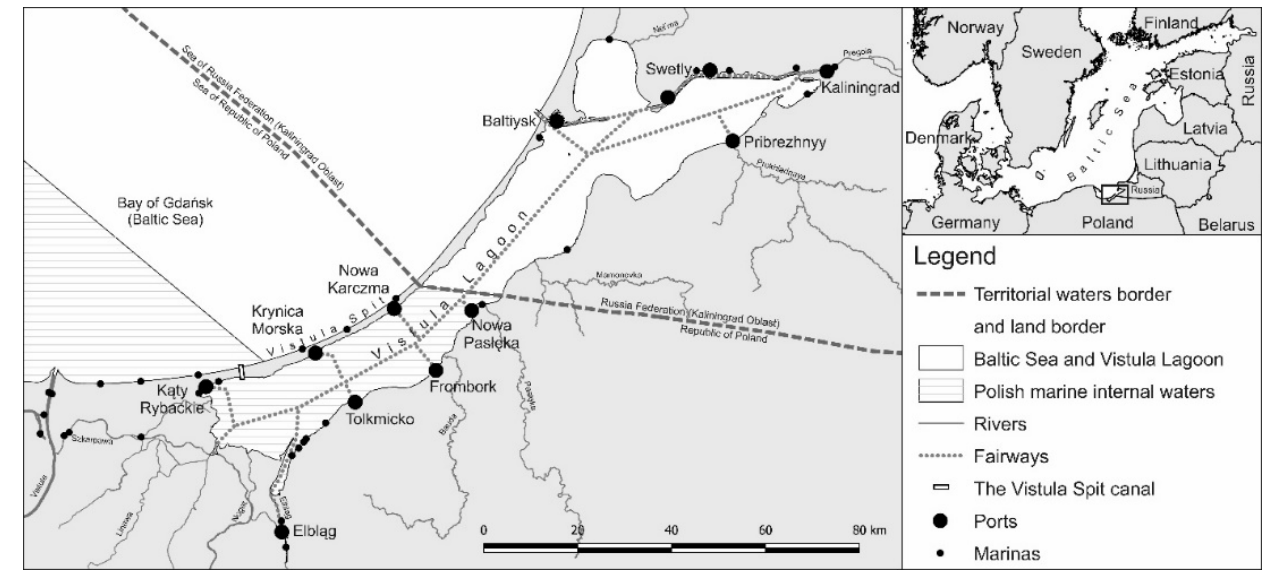

Figure 1. Spatial scope of research in the area of the Vistula Lagoon.

The Vistula Lagoon is characterized by shallow depth ( $2.7 \mathrm{~m}$ on average) and moderately good conditions for sailing, mainly for small vessels. The ripple depends on the wind strength, but is usually around $0.1 \mathrm{~m}$. However, strong winds change the water level in the reservoir by up to $1.2 \mathrm{~m}$. Due to the small depth of the Polish part of the lagoon, vessels with a draft of more than $1.0 \mathrm{~m}$ must navigate via fairways, where mostly a draft of up to $1.5 \mathrm{~m}$ (maximum $2.2 \mathrm{~m}$ ) is allowed. The main fairway is part of the international waterway E70 and runs along the border of the Pomeranian and Warmian-Masurian voivodeships [21]. Both the main fairways and the approach fairways to ports are becoming shallower relatively quickly due to the unstable ground of the bottom of the reservoir. This is a significant constraint on the development of water transport and port cities. Moreover, active maintenance of fairways generates very high costs [22].

Due to the lack of a direct connection between the Polish part of the Vistula Lagoon and the Baltic Sea, in 2019 the Polish government initiated construction of the Vistula Spit canal. This investment is to bring independence from Russia and stimulate the development of ports and marinas. The Sea Port in Elblag is supposed to be the main beneficiary. The 
construction of a new waterway will complement the existing transport infrastructure. This will enable vessels with a draft of up to $4.0 \mathrm{~m}$ to navigate this section.

The Vistula Lagoon is currently used mainly for tourism and as a fishery, including recreational fishing [23]. The main advantages of the region include sandy beaches on the side of the open sea, location on two water bodies and unique fauna and flora habitats under environmental protection, including NATURA 2000. Passenger shipping primarily has importance for tourism and is an attraction in itself, which seasonal tourists are eager to enjoy.

\subsection{Methodology}

In order to achieve the objective of the article, small-scale research methods and field studies were used. In the part regarding an identification of development plans contained in planning and strategic documents, the desk research method and the technique of qualitative analysis of their textual and graphic content were used. The criterion for the selection of documents was their objective scope, including visions for the development of tourism and transport for the functional area of the Polish part of the Vistula Lagoon. The topics in focus for the research were primarily related to: maintenance, modernization and expansion of the hydro-technical infrastructure, the planned network of ferry connections and the development of tourist traffic, including international tourism. Thus, 14 documents at the local level, 5 at the regional level and 2 supra-regional level documents were analyzed. Ship owners' opinions regarding their current activity and the development plans were examined using an electronic questionnaire sent to all six companies offering organized passenger transport services in the Vistula Lagoon (the list of ship owners was provided by the Maritime Office in Gdynia). In this way, a complete set of responses was collected in the period from February to May 2019. In most cases, it was necessary to contact company representatives several times with a request to fill in the questionnaire. Ship owners were generally reluctant to share their insights as well as company performance data and development plans. This is in line with the conclusions of Luhtala et al. [24] and, in this light, completing the responses among the entire group of stakeholders is very valuable [25]. The survey consisted of 11 questions concerning basic information about the company, operated connections on the Vistula Lagoon, passengers served, as well as an assessment of the functioning and vision of development. The survey was conducted via the Internet. Ship operators received a questionnaire that they had to complete and return. In addition, a telephone conversation was conducted with each of the operators, which refined the answers and explained any misunderstandings. Additionally, in order to characterize the current condition of the infrastructure and the operation of the water transport and tourism system in the region, field studies (participant observation) were conducted in all localities on coastline of the Polish part of the lagoon, and unpublished data from the Harbor Master's Office in Elblag (analysis of quantitative data of passengers on cruises on the Vistula Lagoon in 2007-2019) were used. As noted by Butowski [2], the combination of quantitative and qualitative analyses is the right approach to inventorying the needs of various tourism stakeholders and shaping sustainable tourism in a wide paradigm of sustainable development.

\section{Results}

\subsection{Current Operation of Passenger Shipping}

The Polish part of the Vistula Lagoon is characterized by low traffic with most of the vessels being small yachts. The regular and all-year-round water transport includes only freight transport, mainly between the ports in Elblag and Kaliningrad. Passenger shipping takes place mainly during the summer tourist season. It generally lasts from the beginning of May to the end of September (trips on weekends and bank holidays), although the peak season is during the summer school holidays in July-August (daily trips). Taking into account the summer season, the share of passengers is in May 7\%, June 18\%, July 33\%, 
August 34\% and September $8 \%$. During the rest of the year, there are only occasional, custom-made cruises, but their share in total transport is marginal.

Transport services on the Vistula Lagoon are provided by six ship owners: AQUATOM, EFB Partner, Elster, WinGT, Wiwaldi Junior and Żegluga Gdańska. Their regular offer includes connections between the ports of Krynica Morska and Tolkmicko and Krynica Morska and Frombork, as well as round cruises starting and ending in the same ports of Krynica Morska and Frombork (Figure 2). Round cruises are of a typically tourist nature, and their main attraction is sailing and admiring the scenery. Although connections between various ports provide an alternative to other types of transport and enable people to travel, e.g., for work purposes to seasonal workplaces, they are also dominated by tourist traffic, including the crossings of the southern coast inhabitants to the beaches of the Vistula Spit. Bridging waterside tourist destinations with the use of passenger water transport is a well-known way of organizing tourist traffic in functional areas [26,27]. Connecting the two shores of the basin would play a greater role in transit if car and passenger ferries were launched. Access to the towns and villages located on the Vistula Spit is possible only by a single-lane voivodeship road, whose capacity is a significant limitation for traffic in the peak summer season. Cruises from Krynica Morska, which is the main tourist center of the Polish part of the Lagoon, to Tolkmicko and Frombork usually take the form of several-hour trips combined with sightseeing in these places.

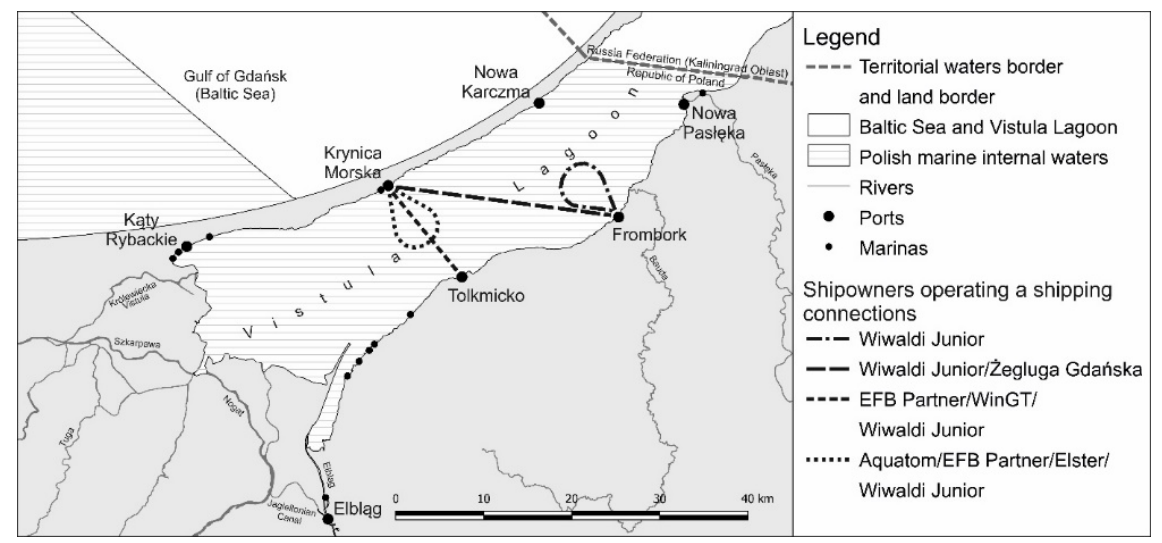

Figure 2. Passenger shipping in the Polish part of the Vistula Lagoon.

The basic characteristics of services provided by ship owners in the Polish part of the Vistula Lagoon are presented in Table 1. Most of the ship owners have one vessel each, and there are 8 in total, with a total maximum capacity of 708 passengers. The average age of the vessels is about 42 years, with only two under 10 years old. The vessels most frequently chosen by tourists are the largest ones: "Anita" from Żegluga Gdańska (Figure 3) and "Monika" belonging to EFB Partner. In total, the ship owners declare carrying about 90,000 passengers per year.

Each vessel that leaves or enters a port must report this to the appropriate Harbor Master's Office, stating the number of passengers. Thus, collected data best illustrate the actual functioning of navigation in ports of the Vistula Lagoon (Figure 4). Departing passengers are those who leave from the analyzed ports, and arriving passengers are those who enter them. The difference between the values for each year comes from trips that started or ended in ports or harbors outside the analyzed area. These are additional trips beyond the regular transport offer. There is a noticeable upward trend in the number of passengers served in 2007-2019. Apart from the growing popularity of spending holidays at the Polish seaside, the weather has a great influence on tourism in the region. It was the main reason for lower traffic in 2012-2015. Over the past four years, about 150,000 people used the services of ship owners every year. The difference between this value and the declared total number of passengers presented in Table 1 results from the method of counting passengers. This mainly concerns return tickets assigned to one passenger who is counted on arrival and departure at both ports. Taking into account particular ports, 
Krynica Morska is of the greatest importance for traffic on the Vistula Lagoon, which is the beginning and end of $65 \%$ of all cruises. As much as $60 \%$ of transport offered there concerned round cruises. Frombork is another important port from the point of view of passenger shipping, generating 27\% of traffic. In Tolkmicko and Katy Rybackie, 5\% and 3\% of passengers were handled, respectively.

Table 1. Characteristics of services provided by ship owners on the Vistula Lagoon.

\begin{tabular}{|c|c|c|c|c|c|}
\hline Ship Owner & $\begin{array}{l}\text { Year of Launching } \\
\text { the Business }\end{array}$ & $\begin{array}{l}\text { Period of Offering } \\
\text { Regular Cruises }\end{array}$ & $\begin{array}{l}\text { Number of Owned } \\
\text { Vessels/Total Seats }\end{array}$ & $\begin{array}{l}\text { The Sum of Regular } \\
\text { Cruises per Day }\end{array}$ & $\begin{array}{c}\text { The Average Sum of Passengers } \\
\text { Transported per Year }\end{array}$ \\
\hline AQUATOM & 2011 & 15 June-30 Sep. & $3 / 36$ & 8 & $\sim 15,000$ \\
\hline EFB Partner & 2011 & 01 May-30 Sep. & $1 / 211$ & 4 & $\sim 20,000$ \\
\hline Elster & 2008 & 01 May-31 Aug. & $1 / 26$ & 6 & $\sim 13,000$ \\
\hline WinGT & 2012 & 01 May-30 Sep. & $1 / 75$ & 6 & $\sim 15,000$ \\
\hline $\begin{array}{l}\text { Wiwaldi } \\
\text { Junior }\end{array}$ & 2016 & 01 July-31 Aug. & $1 / 110$ & 4 & no data \\
\hline $\begin{array}{l}\text { Gdańsk } \\
\text { Shipping }\end{array}$ & 1946 & 01 May-31 Aug. & $1 / 250$ & 4 & $\sim 27,000$ \\
\hline
\end{tabular}

Source: Own elaboration based on ship owners' responses in the survey.

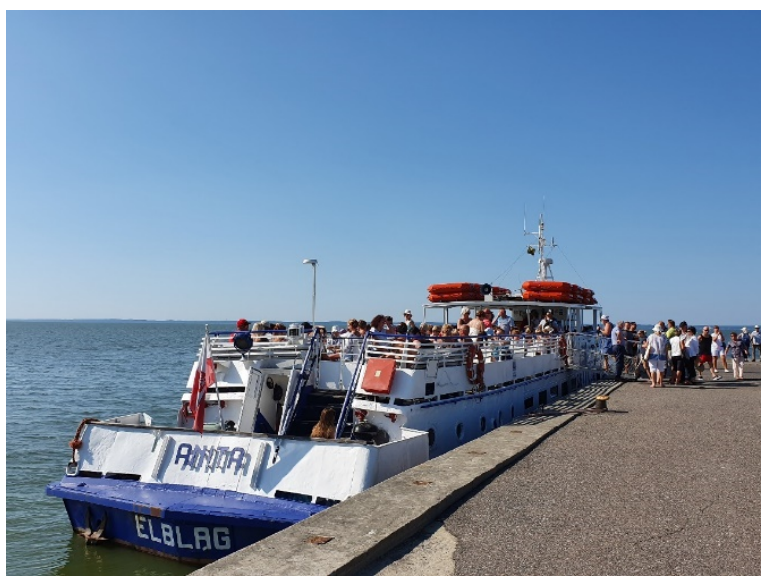

Figure 3. Passenger ship “Anita" owned by Żegluga Gdańska departs from Frombork.

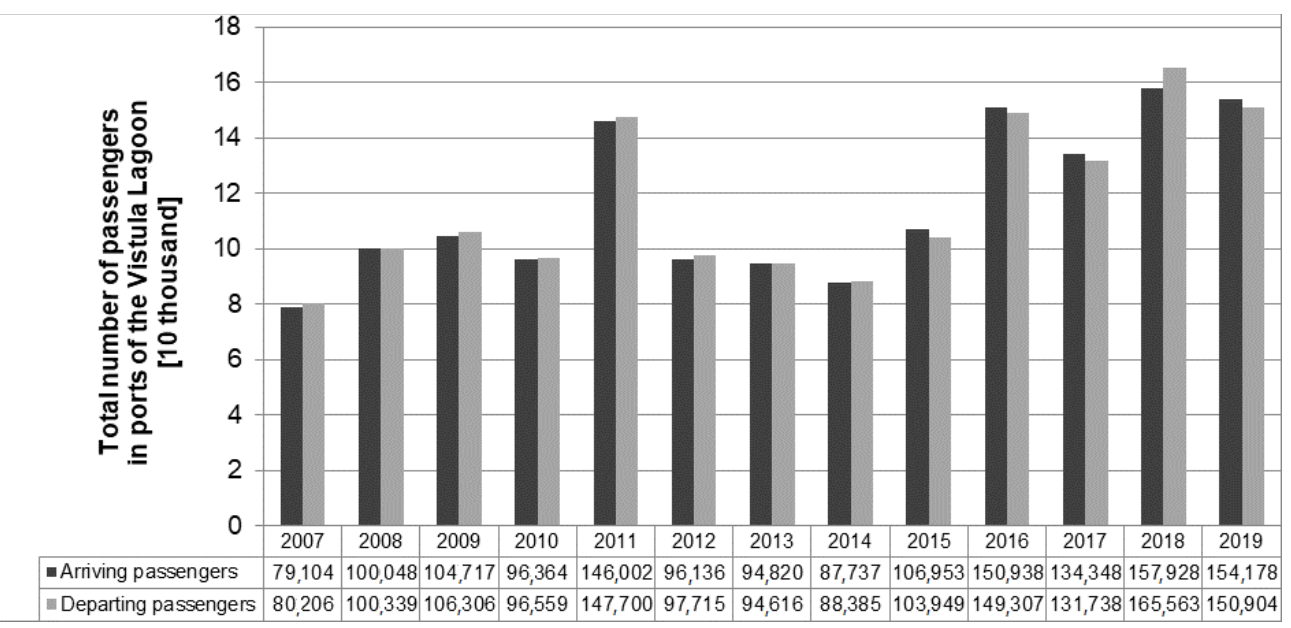

Figure 4. Passengers on cruises on the Vistula Lagoon in 2007-2019. Source: own elaboration based on the data of the Harbor Master's Office in Elblag.

The seaport in Elblag is the largest port in the region. It is located on the Elblag River, along which traffic flows towards the Vistula Lagoon (passenger and freight) and the upper 
course of the river (passenger traffic). Although historically Elblag had ferry connections, incl. with Krynica Morska, there are currently no regular passages to ports of the Vistula Lagoon. The reason may be the peripheral location in relation to the waters of the reservoir and the small tourist offer of the city. The vast majority of all passenger trips are towards the headwaters of the river. The regular offer of local ship owners does not include regular connections with ports of the Vistula Lagoon.

\subsection{Development of Tourism Water Transport in the Spatial Policy}

The waters of the Vistula Lagoon, as a functional area, are not yet covered by the maritime spatial plan, which may particularly affect the activity and economic efficiency of tourist passenger shipping and the improvement of international cooperation [25,28]. Administratively, the Polish part of the Vistula Lagoon lies within seven municipalities and is divided between two voivodeships (Figure 5). Particularly, the division at the regional level does not facilitate effective regional governance. The two voivodeships do not always agree, which was most clearly visible in the context of building a new waterway connecting the Vistula Lagoon with the Bay of Gdańsk. Approval of the investment and recognition of it as an important opportunity for development was confirmed in the planning and strategic documents of the Warmian-Masurian Voivodeship. The self-government of the Pomeranian Voivodeship, through the territory of which most of the planned investment would run, including the key ditch of the Vistula Spit, stood in opposition to this vision. The documents of this voivodeship cautiously address the issues a new waterway, pointing to the necessity of conducting multi-criteria analyses in order to assess the potential environmental and economic impact of the investment in as much detail as possible. Attention is drawn to the unprofitability of the entire undertaking and the inadequate level of benefits in relation to costs and environmental effects. Modernization of the inland waterway on the Szkarpawa River, which currently has class II navigability, is indicated as an alternative. Apart from that, the goals and planned activities in the documents of both voivodeships are mostly consistent. They concern, among others, modernization of fairways on the Vistula Lagoon and inland waterways, construction of new and extension of existing ports and marinas, as well as development of their tourist functions. There is a noticeable prospect of introducing sea connections between the ports of Tricity and Elblag and the Kaliningrad Oblast. In this case, both parties are applying to the central administration to remove all legal barriers to ensure free international shipping [29-33]. It is important to note that some of these arrangements are a continuation of previous editions of the documents, which means that development plans have not been fully implemented and there are still significant delays in the development of the hydro-technical infrastructure.

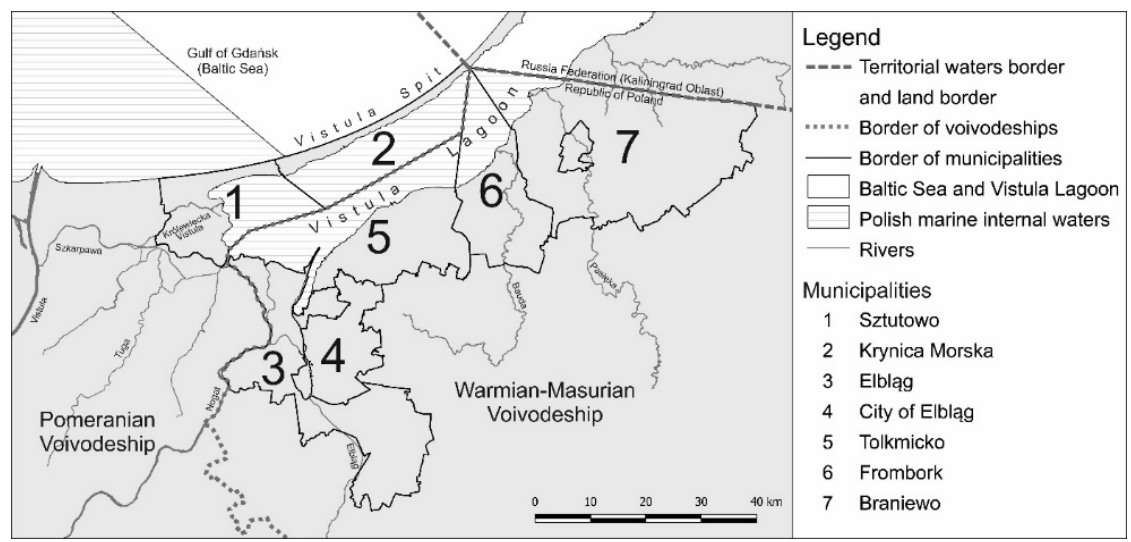

Figure 5. Administrative division of the Polish part of the Vistula Lagoon region.

The division of the Vistula Lagoon region between two voivodeships was one of the reasons for drawing up sectoral documents for the functional area. In the context of the conducted analysis, two have been selected that have the greatest impact on the 
development of shipping in the Vistula Lagoon. The aim of the first one is to develop tourism and tourism-related activities in the region. The strategy assumes a wide range of investment and management activities which, despite the perspective of passing time, have not been fully implemented. The most noticeable result is the numerous modernizations and construction of marinas. From the perspective of organized passenger shipping, only one regular water connection, Tolkmicko-Krynica Morska, was launched [34]. Unfortunately, in 2016 the entity responsible for carrying out the strategy was dissolved. Another document was created on the initiative of the municipality of Tolkmicko and in cooperation with local governments of the southern part of the region. Its main goals are: expanding the offer of passenger shipping to catering for tourist traffic (Tolkmicko, Frombork, Nowa Pasłęka), launching seasonal ferry crossings as an alternative route to the Vistula Spit (from Tolkmicko), developing cross-border passenger tourist traffic from the port in Frombork, reconstructing the check-in point in Nowa Pasłęka, opening the Vistula Lagoon for Baltic shipping through a shipping canal across the Vistula Spit [35].

To analyze the vision of local governments in the context of the development of water tourism, two types of documents were taken into account: "studies on conditions and directions of spatial management of a municipality" and "development strategies of a municipality". These are the most important documents defining the spatial policy and development objectives in each municipality. Seven municipalities were taken into account (Braniewo, Frombork, Tolkmicko, Krynica Morska, Sztutowo, Elblag and the city of Elblag) within whose borders marine internal waters of the Vistula Lagoon are situated. The documents sometimes formulated problems that should be addressed in the context of the functioning of shipping on the Vistula Lagoon, mainly issues of poor-quality infrastructure, lack of direct connections with waters of the Bay of Gdańsk and suspended cross-border connections. All objectives related to the subject of this analysis can be divided into three categories: (1) related to the construction or modernization of infrastructure, (2) developing the offer of passenger shipping, and (3) methods of management. The first one primarily includes investments aimed at improving the insufficient condition of the hydro-technical infrastructure. Such activities are the subject of conclusions in the documents of each municipality. The most frequently mentioned objectives are: modernization and expansion of the existing ports, construction of tourist service facilities in ports, modernization and construction of new marinas, deepening of fairways and waterways to reach appropriate technical parameters, and their maintenance. Some municipalities see a great opportunity for the development of the tourism and transport industry in the construction of a road connecting the Vistula Lagoon with the Bay of Gdańsk. The municipality of Krynica Morska is the only one to object to this investment and, in its development strategy, it considers it a threat to the municipality's development. In the category of objectives related to the offer of passenger shipping, local governments focus on restoring the past connections on the Vistula Lagoon and introducing new ones. These connections are to restore regular passenger navigation in the port of Nowa Pasłęka, launching cruises between Katy Rybackie and Frombork and Tolkmicko, as well as creating the first passengercar ferry crossing on the Tolkmicko-Krynica Morska route. Such conclusions can be found in half of the analyzed documents, but they do not specify the role of local governments in their implementation. Rather, they indicate the desired direction of shaping the transport offer for ship owners representing the private sector. The management objectives include various types of direct and indirect support activities for the transport and tourism industry. They are often formulated very imprecisely, but they express the positive attitude of local governments towards the development of shipping. The most important ones include: increasing the importance of cruises to Krynica Morska in order to relieve the road transport system, incorporating sea border crossings into local border traffic, supporting public ferry transport, promoting the region for tourism and creating conditions for the development of tourist functions [36-49]. 


\subsection{Ship Owner's Perspective}

Currently, passenger water transport services in the Vistula Lagoon are provided by six ship owners. This section presents a synthetic description of the functioning and development plans of the analyzed ship companies. The information contained here comes from answers to a survey. Understanding the ship owners' perspective, who belong to the key entrepreneurs in the tourism industry in the region, is vital to complement the current state of knowledge and it allows a better understanding of their real needs.

Most of the ship owners started their business in the Vistula Lagoon quite recently, in 2008-2016. Their regular transport offer has not changed and they still operate on the same routes. Żegluga Gdańska is an exception, as it started its activity in 1946 and, in its history, it has operated on the following routes: Elblag-Krynica Morska, Elblag-Tolkmicko, Elblag-Kaliningrad, Frombork-Kaliningrad, Frombork-Svietlyj. As the company explains, the reason for cancelling these routes was primarily lower than expected interest on the part of passengers, termination of the contract for the so-called Water Tram from Elblag to the Vistula Spit and the introduction of visas to Russia. International traffic was an important element of shipping in the Vistula Lagoon, and the difficulties associated with crossing the border effectively discouraged both potential tourists and ship owners. The historical connections show the position of the ports in Elblag and Frombork, which are the only ones with border checkpoints for international passenger transport. Unfortunately, they are not currently used. In the context of the current and limited shipping offer on the lagoon, it is important to note that, under the current conditions, none of the ship owners are planning to expand their activity with new connections. If it were possible to cross the sea border on the Vistula Lagoon freely, only one ship owner declared launching a connection on the Krynica Morska-Kaliningrad route (EFB Partner with the ship "Monika"). The remaining entrepreneurs point to the lack of appropriate technical facilities in ports to handle international crossings and the unprofitability of such an offer related to the expected low interest of passengers. This approach of the ship owners significantly reduces the probability of implementing the vision of the development of shipping between Polish and Russian ports, defined by Gumenyuk and Studzieniecki [11].

The Vistula Lagoon is only considered attractive for passenger navigation during the summer season. This is directly related to tourists' stays and the activities of other entities in the tourism industry. The advantages of the region include a slow but noticeable increase in the number of tourists, although this is not always associated with an increase in interest in cruises. Weather conditions are very important for tourism-based recreation. In general, the Vistula Lagoon is safe for navigation, but sometimes there are sudden changes in the weather, which can ground ships in ports. Another important limitation to the development of the region's tourism industry is the dominance of Krynica Morska as the most popular destination among tourists and a poor tourist offer of towns located on the southern shore of the lagoon. This naturally limits the motives for tourist traffic between ports of the basin.

Off-season passenger shipping operates only occasionally, e.g., in the form of chartered cruises during corporate or private events. Although the waterway between ports of the northern and southern shores of the Vistula Lagoon is much shorter, due to the relatively low speed of sailing it is usually not competitive for car traffic [50]. In the questionnaire, ship owners were asked whether, if there were support from local/state authorities, they would be willing to launch all-year connections, which would relieve public roads. Only one of them replied in the affirmative. By contrast, the others indicate a probable low interest in cruises and the unprofitability of operations even in the conditions of economic support for enterprises, unfavorable weather conditions and freezing of the basin, which may effectively impede implementation of regular water connections.

Building a waterway connecting the Vistula Lagoon with the Bay of Gdańsk is a chance for the development of water transport and water tourism in the region. Its first stage, the shipping canal across the Vistula Spit, is to be completed in 2022. Ship owners' opinions on the impact of the investment on their activities are divided. EFB Partner, 
Wiwaldi Junior and Żegluga Gdańska see it as an opportunity to carry out round trips with sailing to the Bay of Gdańsk and to launch new connections, including the Elblag-Gdańsk and Elblag-Krynica Morska routes. Modernization of the fairway on the Elblag River along with removing the current pontoon bridge and building a drawbridge is planned as part of the construction of the waterway. The pontoon bridge is often closed due to too low or too high water levels. This holds up regular connections, so eliminating this problem in the future may encourage ship owners to resume shipping on this section. It is likely that the construction of an independent connection between the Polish part of the Vistula Lagoon and the Bay of Gdańsk will result in increased yacht traffic in the basin's ports and it will increase the total number of tourists. This may create a slightly greater interest in the offer of passenger shipping. Four ship owners do not see this investment as having a significant impact on their activity. These are mainly owners of small vessels, whose operational capabilities do not allow them to go out into the open sea.

The last issue raised in the survey is the identification of problems in the functioning of passenger navigation in the Vistula Lagoon. Some of them have already been signaled earlier. In general, problems can be divided into two categories: economic and infrastructural. The former primarily concerns high costs of year-round maintenance of vessels, including employment of seasonal crew. Due to the old age of most of the vessels, they require frequent repairs and adaptation to the binding legal standards. According to one of the ship owners, their activity should be subsidized from the budgets of local governments, which receive revenues from the tourism sector. The category of infrastructural problems includes shallow depths of fairways in the lagoon and approach fairways to ports, insufficiently developed infrastructure of ports and marinas, including a lack of facilities for tourists. Infrastructural limitations are part of the problems that may be influenced by local government, and cooperation between the authorities and ship owners should be especially encouraged in this field.

\subsection{Comparision of the Development Visions of the Passenger Shipping on the Vistula Lagoon}

In the context of the presented research objective, the three most important stakeholders of the analyzed tourism space can be identified: entrepreneurs, the authorities and tourists. Ship owners belong to the group of entrepreneurs who shape the tourist offer with their activities. Their motive for their activity is economic profit, built on the basis of tourists' expenses. Local authorities represent the community and have an indirect impact on the development of tourism in the form of shaping spatial policy or financing the infrastructure [51]. Their activities focus on the growing importance of tourism in the region, which translates into social and economic benefits. Tourists primarily care about the wide range of services offered, their high quality and low price. The latter was one of the main reasons for abandoning the idea of restoring hydrofoils to operate some of the trips. The costly operation of vessels would force the ship owner to set relatively high prices for tickets, which would probably result in little interest from passengers, despite the distinctive type of the ship among other vessels. All these stakeholders are closely related to one another, but their individual goals do not fully converge. The common feature of entrepreneurs, authorities and tourists is a desire to develop tourism and commercialize the region's resources.

The impact of tourism on the socio-economic development of a coastal cross-border region, such as the Vistula Lagoon, is unquestionable [52]. However, the scale of this impact is still considered insufficient. The sources of this phenomenon include historical conditions (socio-economic problems) and the fragmentation of the functional area between various entities of local governments and managing institutions. The area of the Vistula Lagoon is peripheral to the administrative division at the regional level and has a low priority for the authorities of both voivodeships [14]. In recent years, their attention has focused on the construction of the Vistula Spit canal. Apart from the different attitude to the implementation of this trans-regional investment presented in the documents, Wendt and Wiskulski [53] indicate the concerns of the Pomeranian Voivodeship against emerging 
competition on the market of port services in the neighboring voivodeship. However, this conflict has a symbolic meaning, as the government has adopted a special act for the construction of a new waterway, which, among others, excludes the need for the investment to comply with the applicable planning and strategic documents. In the context of the multitude of borders and divisions of the Vistula Lagoon between various local and regional governments, it should be remembered that each of them seeks their own interests. This factor hinders achievement of the jointly declared goals, although many projects have already been implemented, for example investments under the program of activating water tourism "Pẹtla Żuławska". Good examples of cooperation between local governments include shaping a common vision of development in sectoral documents. However, the possibilities of a direct influence of local governments on the functioning of tourism are limited. This applies primarily to free-market mechanisms in the private sector, but also to significant financial constraints to making capital-intensive investments.

The previously presented local governments' and ship owners' visions for development are partially convergent, especially in terms of improving the quality of the infrastructure of ports and fairways. According to Kizielewicz [9], in the opinion of port managers, ship owners primarily care about the good accessibility of the quays from the water side, the services and facilities for passengers, and the accessibility of cities and tourist attractions. Local governments and port managers wanting to increase the competitiveness of their ports should strive for high-quality passenger service and transport accessibility. However, often the economic calculation does not allow them to make costly investments in seasonal shipping. On the other hand, in less developed localities, the construction of hydro-technical infrastructure for the purposes of water tourism results in a rapid development of the local economy, which may be an important reason to undertake investment activities [54,55]. An important difference in both visions is a lack of declarations for launching new connections in shipping on the Vistula Lagoon, despite clear recommendations to create them from the local governments' perspective. The recommendations contained in the documents are not binding for the private sector, and one should not really expect entrepreneurs to undertake economically unjustified actions. Subsidizing transport activities, increasing tourist traffic and developing tourist functions in towns apart from Krynica Morska may influence launching new connections. The poor tourist offer of the towns on the southern shore of the Vistula Lagoon is both the cause and effect of the low importance of passenger navigation between both sides of the basin. This situation resembles a vicious circle, i.e., tourists do not go to other ports to stay there, because there are not enough attractions, and these do not appear because the traffic is too small for profitable economic activity. On the other hand, financial support for small entrepreneurs should be long-term and carried out in parallel with social activities that will inspire the trust of local authorities, and ship owners, along with the assistance offered, will adopt the proposed model of operation [56].

Understanding the role of local communities and identifying their needs is the core of effective management and creating adequate visions of development. In the area of the Vistula Lagoon, there is an urgent need to involve local communities in shaping development policies. This can be helped by the local authorities' attitudes which will inspire trust and ensure business continuity [8,56]. However, it should be borne in mind that the lack of sense of agency of the stakeholders of the participation process and the exclusion of at least some beneficiaries of the formulated arrangements may result in failure to achieve the intended goals [57].

\section{Discussion}

Tourism, in which passenger shipping in the Vistula Lagoon region is an important part, is a key sector of economic activity for local governments. In the analyzed area, a slow increase in the number of tourists is observed, which gives hope for a further increase in the competitiveness of the region in relation to other tourist destinations on the Polish coast. It is also a result of improving transport accessibility and modernization of some 
ports and marinas. The current offer of passenger shipping is relatively modest, taking into account the historical connections between the ports in the Polish part of the lagoon and international cruises. The expansion of ship owners' transport activities is closely related to the emergence of favorable conditions to provide transport services, such as improving the quality of port infrastructure to serve ships and passengers, improving navigable conditions in the waters of the basin, removing obstacles to international traffic and a growth of the number of people interested in cruises. It is satisfactory that the majority of development goals coincide between ship owners and the content of the binding planning and strategic documents. The greatest similarities are related to the modernization and expansion of infrastructure as well as activities aimed at popularizing tourism in the region. The main discrepancies in the presented visions of development concern the offer of passenger shipping services. Ideological directions of its expansion expressed by local governments are not reflected in the interests of ship owners. Economic calculation is the leading criterion for verification if the vision is to come true.

The conducted research made it possible to identify the conditions for the functioning of passenger shipping in the Vistula Lagoon, which, due to the division by the state border, is an area with a special legal situation. At the same time, the research area is a very attractive tourist destination. A relatively shallow water reservoir, safe for navigation and water sports, has great potential. Paradoxically, the Vistula Spit ditch, which is being carried out, may be a development impulse that will increase the number of tourists visiting this region of the country. The greater number of tourists, and thus the potentially greater value of the demand for shipping services, may contribute to greater competition among ship owners and improve the offer of connections and the standard of ships. International shipping between Poland and the Russian Federation would be a great attraction. Due to customs issues, there would be a chance of linking tourism shipping with cross-border trade. However, in order to return to this issue, a new opening in Polish-Russian relations is needed. The current geopolitical situation is not conducive to these solutions, although local governments would gladly accept such a solution.

Furthermore, the results of this study constitute an important voice of ship owners, whose position is under-represented in the discussion on the development of tourism in planning processes. This diagnosis presents the perspective of ship owners in a fairly general way, which made it possible to identify in the documents the similarities and differences with the objectives of the development of passenger shipping. Including them in the processes of constructing local spatial policies seems to be necessary to achieve real benefits from the cooperation of the public and private sectors and to achieve the goals set for oneself, which can sometimes be divergent. In such direct cooperation with representatives of local governments, ship owners would be more likely to provide detailed information about their activities, which they are generally reluctant to share. The greatest challenges faced by passenger shipping in the Vistula Lagoon include the increase in the involvement of ship owners in shaping the development of tourism (including awareness of the advantages of such cooperation) and the even improvement of the quality of water infrastructure and tourist facilities in the entire functional area of the reservoir.

The next stage of the research presented in the article suggests the carrying out of interviews with tourists visiting the area of the Vistula Lagoon in the summer season. The analysis of their responses would allow the identification of the needs and expectations in terms of shaping shipping connections in the Vistula Lagoon. Due to the seasonality of tourist traffic, the best time to carried out the research is from 15 July to 15 August, although these plans must take into account possible complications resulting from the COVID-19 pandemic and applicable restrictions. Additionally, it is worth repeating the survey among ship owners to see if their voice is more audible in the public sector and how local tourism will be affected by currently implemented hydrotechnical investments. In connection with the COVID-19 pandemic and the observed decrease in tourist traffic [58-60], a comparative analysis of the situation of ship owners will be performed after all restrictions are in force. Additional conditions, the fulfillment of which will enrich the cognitive functions of the 
study, are: completion of the construction of the Vistula Spit canal, updating of planning and strategic documents, adoption of the maritime spatial plan for the Vistula Lagoon.

\section{Conclusions}

The article presents a research procedure aimed at contributing to filling the knowledge gap in the meeting, systematization and presentation in the description of the potential of the Polish part of the Vistula Lagoon in the context of the functioning and development of passenger shipping and the verification of the visions of ship owners and local governments. The article presents a proprietary research consisting of collecting information from shipowners, unpublished materials on the demand and supply of shipping services, planning and strategic documents of local governments. All these studies were analyzed and structured. By verifying the plans for the functioning and development of passenger shipping on the Vistula Lagoon by both parties, the following questions were answered:

(1) Numerous administrative divisions of the Polish part of the Vistula Lagoon basin make it difficult to develop common visions for the development of passenger shipping due to, inter alia, the planning authority of each of the communes. An example of cooperation in the field of creating a common vision of passenger shipping development are strategic documents at the supra-regional level for a group of interested communes, but not all of them. The construction of the Vistula Spit canal turned out to be the most important controversial element among the analyzed visions of local and regional self-governments.

(2) Ship owners' needs and development plans are partially in line with the provisions of planning and strategic documents. The similarities include the promotion of tourism in the region, the improvement of the quality of hydro-technical infrastructure and the elimination of obstacles to international traffic with Russia. However, the discrepancies include the facts that the documents do not contain the co-financing of ship owners' activities; there are excessive expectations of local governments towards the shaping of the network of ferry connections by the ship owners, and moderate possibilities of the surveyed ship owners to use the Vistula Spit canal in passenger tourist shipping.

(3) Most local governments see the construction of the Vistula Spit canal as opportunities for passenger shipping, although the investment is focused primarily on freight water transport. Only half of the currently operating ship owners consider using the investment in their future shipping offer. Both sides expect an increase in tourist traffic following the construction of the canal, including an increased demand for tourist shipping.

The main recommendations resulting from the analyses carried out include the need to jointly create a tourist product such as passenger navigation connections on the Vistula Lagoon, their promotion, and improvement of the quality of services provided. The development impulse may be the Vistula Spit canal, but the opening of the sea border with the Russian Federation would be of particular importance in the development of connections.

In terms of potential further research directions, it is required to verify the possibility of developing passenger ferry connections in the Vistula Lagoon as a unique natural area. The development of ferry connections could refer to transport policies at the European Union level, which impose the need to reduce emissions of exhaust gases and other harmful pollutants. The reservoir of the Vistula Lagoon is a unique place that is appropriate for the development of tourism, including ferries, and a common vision of the development of shipping, e.g., based on low-emission ships, has to be developed both at the level of local governments and supported by the national government.

Author Contributions: Conceptualization, K.P. and M.P.; methodology, K.P. and M.P.; formal analysis, K.P. and M.P.; investigation, K.P.; resources, K.P.; data curation, K.P.; writing-original draft preparation, K.P. and M.P.; visualization, K.P.; supervision, K.P. and M.P.; project administration, K.P.; funding acquisition, M.P. All authors have read and agreed to the published version of the manuscript.

Funding: This research received no external funding.

Institutional Review Board Statement: Not applicable. 
Informed Consent Statement: Not applicable.

Data Availability Statement: Not applicable.

Conflicts of Interest: The authors declare no conflict of interest.

\section{References}

1. Stănciulescu, G.C.; Strugari, D.-M. Considerations about Lagoon Tourism in Europe. Cactus Tour. J. 2014, 9, 6-11.

2. Butowski, L. Sustainable Tourism: A Human-Centered Approach. Sustainability 2021, 13, 1835. [CrossRef]

3. Kizielewicz, J. Prospects of Development of the Cruise Ship Tourism Market-The Case Study of the Baltic Sea Region. Res. Pap. Wrocław Univ. Econ. 2019, 63, 244-255. [CrossRef]

4. Korneevets, V.S.; Kropinova, E.G.; Dragileva, I.I. The Current Approaches to the Transborder Studies in the Sphere of Tourism. Int. J. Econ. Financ. Issues 2015, 5, 10.

5. Więckowski, M. Tourism Development in the Borderlands of Poland. Geogr. Pol. 2010, 83, 67-81. [CrossRef]

6. Więckowski, M.; Cerić, D. Evolving Tourism on the Baltic Sea Coast: Perspectives on Change in the Polish Maritime Borderland. Scand. J. Hosp. Tour. 2016, 16, 98-111. [CrossRef]

7. Kropinova, E. Transnational and Cross-Border Cooperation for Sustainable Tourism Development in the Baltic Sea Region. Sustainability 2021, 13, 2111. [CrossRef]

8. Przedrzymirska, J. Engaging Local Communities in the Process of Participatory Management in the Coastal Zone-The Experience of the Region of the Vistula Lagoon. BMI 2016, 31. [CrossRef]

9. Kizielewicz, J. Potencjał infrastrukturalny portów morskich jako element konkurencyjności na rynku usług morskiej żeglugi wycieczkowej. Folia Tur. Akad. Wych. Fiz. Im. B. Czecha w Krakowie 2017, 42, 69-85. [CrossRef]

10. Łapko, A.; Hącia, E.; Wieczorek, R. Collection of Waste from Passenger Ships and Its Impact on the Functioning of Tourist Port City Świnoujście. Sustainability 2021, 13, 2133. [CrossRef]

11. Gumenyuk, I.; Studzieniecki, T. Current and Prospective Transport Connections between Poland's Border Voivodeships and Russia's Kaliningrad Region. Balt. Reg. 2018, 10, 114-132. [CrossRef]

12. Belova, A.V.; Fedina-Zhurbina, I.V. The Potential of the Kaliningrad Region in the Development of Health Tourism. In Baltic Region-The Region of Cooperation; Springer Proceedings in Earth and Environmental Sciences; Fedorov, G., Druzhinin, A., Golubeva, E., Subetto, D., Palmowski, T., Eds.; Springer International Publishing: Cham, Switzerland, 2020; pp. 285-296.

13. Kropinova, E.G. Tourism and the Sustainable Development of the Baltic Sea Region. In Decent Work and Economic Growth; Springer Nature: Cham, Switzerland, 2020; pp. 1-16. [CrossRef]

14. Bielecka, M.; Różyński, G. Management Conflicts in the Vistula Lagoon Area. Ocean Coast. Manag. 2014, 101, 24-34. [CrossRef]

15. Anisiewicz, R.; Palmowski, T. Współpraca Polski z Obwodem Kaliningradzkim Federacji Rosyjskiej jako istotny element integracji bałtyckiej [Cooperation between Poland and the Kaliningrad Oblast of the Russian Federation as an important element of Baltic integration]. Prace Studia Geogr. 2016, 61, 13-28.

16. Kropinova, E. Cooperation between Russia and the EU in the Field of Innovative Development of Tourism: The Case of the Lithuania-Poland-Russia Cross-Border Cooperation Programme. Balt. Reg. 2013, 4, 48-57. [CrossRef]

17. Sebentsov, A.; Zotova, M. Kaliningrad as a Tourism Enclave/Exclave? In Tourism and Geopolitics: Issues and Concepts from Central and Eastern Europe; Hall, D.R., Ed.; CABI: Wallingford, UK, 2017; pp. 191-204.

18. Chubarenko, B.; Domnin, D.; Navrotskaya, S.; Stont, Z.; Chechko, V.; Bobykina, V.; Pilipchuk, V.; Karmanov, K.; Domnina, A.; Bukanova, T.; et al. Transboundary Lagoons of the Baltic Sea. In The Diversity of Russian Estuaries and Lagoons Exposed to Human Influence; Kosyan, R., Ed.; Estuaries of the World; Springer International Publishing: Cham, Switzerland, 2017; pp. 149-189, ISBN 978-3-319-43392-9.

19. Różyński, G.; Bielecka, M.; Margoński, P.; Psuty, I.; Szymanek, L.; Chubarenko, B.; Domnina, A.; Tararuk, O.; Przedrzymirska, J.; Zaucha, J. The Management Story of the Vistula Lagoon. In Coastal Lagoons in Europe: Integrated Water Resource Strategies; IWA Publishing: London, UK, 2015; pp. 67-76, ISBN 978-1-78040-628-2.

20. Skrzypczak, A.; Piątkowska, A.; Furgała-Selezniow, G.; Mamcarz, A. Przestrzeń Turystyczna i Potencjał Rekreacyjny Zalewu Wiślanego [Tourist space and recreational potential of the Vistula Lagoon]. In Przestrzeń Turystyczna: Czynniki, Różnorodność, Zmiany [Tourist Space: Factors, Diversity, Changes]; Durydiwka, M., Duda-Gromada, K., Eds.; Uniwersytet Warszawski, Wydział Geografii i Studiów Regionalnych: Warszawa, Poland, 2011; pp. 293-301.

21. Opportunities and Benefits of Joint Use of the Vistula Lagoon (VILA). Katalog Infrastruktury Portów i Przystani Zalewu Wiślanego; Szwankowska, B., Cziubarienko, B., Fiedorowa, G., Gricenko, W., Eds.; Instytut Morski: Gdańsk, Poland, 2014; ISBN 978-8362438-20-4.

22. Różyński, G.; Bielecka, M.; Schönhofer, J. Application of Systems Approach Framework (SAF) to the Vistula Lagoon Case in Poland. Ocean Coast. Manag. 2019, 168, 90-102. [CrossRef]

23. Trella, M.; Mickiewicz, M. Recreational Fisheries Pressure in the Polish Waters of the Vistula Lagoon and Considerations of Its Potential Impact on the Development of Regional Tourism. Fish. Aquat. Life 2016, 24, 231-242. [CrossRef]

24. Luhtala, H.; Erkkilä-Välimäki, A.; Eliasen, S.Q.; Tolvanen, H. Business Sector Involvement in Maritime Spatial PlanningExperiences from the Baltic Sea Region. Mar. Policy 2021, 123, 104301. [CrossRef] 
25. Gómez-Ballesteros, M.; Cervera-Núñez, C.; Campillos-Llanos, M.; Quintela, A.; Sousa, L.; Marques, M.; Alves, F.L.; Murciano, C.; Alloncle, N.; Sala, P.; et al. Transboundary Cooperation and Mechanisms for Maritime Spatial Planning Implementation. SIMNORAT Project. Mar. Policy 2021, 127, 104434. [CrossRef]

26. Tarkowski, M.; Połom, M.; Puzdrakiewicz, K. Bridging Tourist Attractions. The Role of Waterbuses in Urban Tourism Development: The Case of the Coastal City of Gdansk (Poland). GTG 2021, 34, 126-131. [CrossRef]

27. Cheemakurthy, H. Urban Waterborne Public Transport Systems: An Overview of Existing Operations in World Cities; KTH Royal Institute of Technology: Stockholm, Sweden, 2017.

28. Surís-Regueiro, J.C.; Santiago, J.L.; González-Martínez, X.M.; Garza-Gil, M.D. An Applied Framework to Estimate the Direct Economic Impact of Marine Spatial Planning. Mar. Policy 2021, 127, 104443. [CrossRef]

29. Spatial Development Plan for the Pomeranian Voivodeship 2030. 2016. Available online: https://pomorskie.eu/planzagospodarowania-przestrzennego-wojewodztwa-pomorskiego-2030/ (accessed on 15 January 2021).

30. Spatial Development Plan for the Warmian-Masurian Voivodeship. 2018. Available online: http:/ / edzienniki.olsztyn.uw.gov.pl/ WDU_N/2018/4173/akt.pdf (accessed on 15 January 2021).

31. The Regional Strategic Program “Mobile Pomerania”. 2013. Available online: https:// pomorskie.eu/wp-content/uploads/2020 /07/d51015ad-6807-47e8-9faa-2551c8bd6e50.pdf (accessed on 15 January 2021).

32. Strategy for Socio-Economic Development of the Warmian-Masurian Voivodeship Until 2025. 2019. Available online: https://ec. europa.eu/growth/tools-databases/regional-innovation-monitor/organisation/marshal-office-warmia-and-mazury (accessed on 15 January 2021).

33. Development Strategy of the Pomeranian Voivodeship 2020. 2012. Available online: https://pomorskie.eu/wp-content/uploads/ 2020/07/4f9136f9-8e1a-4e00-832a-a95b875dccda.pdf (accessed on 15 January 2021).

34. Development Strategy for Municipalities in the Area of the Vistula Lagoon until 2020. 2007. Available online: https://studylibpl. $\mathrm{com} / \mathrm{doc} / 651179 /$ strategia-rozwoju-obszaru-gmin-nadzalewowych-do-roku-2020 (accessed on 18 January 2021).

35. Development Strategy of Ports and Sea Harbors of the South Shore of the Vistula Lagoon. 2016. Available online: http: / / tolkmicko-umig.bip-wm.pl/public/get_file_contents.php?id=331672 (accessed on 18 January 2021).

36. Study of the Conditions and Directions of Spatial Development in the Municipality of Braniewo. 2007. Available online: https:/ / bipbraniewo.warmia.mazury.pl/akty/693/uchwala-w-sprawie-uchwalenia-zmiany-studium-uwarunkowan-ikierunkow-zagospodarowania-przestrzennego-gminy-braniewo-uchwalonego-uchwala-nr-56-iii-99-rady-gminy-braniewoz-dnia-26-listopada-1999-roku.html (accessed on 18 January 2021).

37. Study of the Conditions and Directions of Spatial Development in the Municipality of Elblag. 2000. Available online: http: / /bip.gminaelblag.pl/system/obj/1197_Studium_uwarunkowan.pdf (accessed on 18 January 2021).

38. Study of the Conditions and Directions of Spatial Development in the Municipality of Krynica Morska. 2002. Available online: http:/ / bip.krynicamorska.tv/strony/menu/32.dhtml (accessed on 18 January 2021).

39. Study of the Conditions and Directions of Spatial Development in the Municipality and City of Tolkmicko. 2015. Available online: http:/ / tolkmicko-umig.bip-wm.pl/public/?id=129787 (accessed on 18 January 2021).

40. Study of the Conditions and Directions of Spatial Development in the Municipality of the City of Elblag. 2010. Available online: http:/ / www.planowanie.umelblag.pl/?q=studium (accessed on 18 January 2021).

41. Study of the Conditions and Directions of Spatial Development in the Municipality of Sztutowo. Resolution No. XXII/144/04 of the Sztutowo Commune Council of November 30, 2004. Sztutowo, Poland 2004.

42. Study of the Conditions and Directions of Spatial Development in the City and Municipality of Frombork. 2015. Available online: http:/ / frombork.samorzady.pl/art/id/538 (accessed on 18 January 2021).

43. The Development Program of the City and Municipality of Tolkmicko for 2016-2025. 2016. Available online: http://tolkmickoumig.bip-wm.pl/public/get_file_contents.php?id=295310 (accessed on 18 January 2021).

44. Strategy of the Municipality of Braniewo. Annex No. 1 to Resolution No. 23/VII/2016 of the Braniewo Commune Council of March 11, 2016. Braniewo, Poland 2016.

45. The Development Strategy of Elblag 2020+. 2014. Available online: https://www.elblag.eu/images/stories/9_strategia/pdf/ Strategia.pdf (accessed on 18 January 2021).

46. The Development Strategy of the Municipality of Elblag for 2016-2025. 2016. Available online: http://bip.gminaelblag.pl/ system/obj/4769_zal._do_uch_157_Strategia_Rozwoju_Gminy_Elblag_2016-2025_tj.pdf (accessed on 18 January 2021).

47. The Development Strategy of the Municipality of Sztutowo for 2014-2020. 2014. Available online: https:/ /bip-v1-files.idcom-jst. pl/sites/3124/wiadomosci/392413/files/uchwala_nr_xxxviii3752014.pdf (accessed on 18 January 2021).

48. The Development Strategy of the City and Municipality of Frombork for 2016-2026. 2016. Available online: http://www. frombork.pl/strona-415-STRATEGIA_ROZWOJU_MIASTA_I_GMINY_FROMBORK_NA_LATA_2016_2026.html (accessed on 18 January 2021).

49. The Strategy for the Socio-Economic Development of the Municipality of the City of Krynica Morska for 2015-2025. 2016. Available online: http:/ / bip.krynicamorska.tv/search/wynik/strat/2383.dhtml (accessed on 18 January 2021).

50. Chubarenko, B.V.; Pilipchuk, V.A.; Domnin, D.A.; Staśkiewicz, A. Shipping on the Vistula Lagoon-Analysis and Potential Partially to Replace Land Transport. Biul. Inst. Mor. w Gdańsku 2016, 31. [CrossRef]

51. Kowalczyk-Anioł, J.; Włodarczyk, B. Przestrzeń turystyczna przestrzenią konfliktu [Tourism space as space of conflict]. Prace Studia Geogr. 2017, 62, 53-72. 
52. Spiriajevas, E. The Impact of Tourism Factor for Development of the South-East Baltic Coastal-Border Regions. Geo J. Tour. Geosites 2008, 2, 118-128.

53. Wendt, J.; Wiskulski, T. Problems of Development of Tourism and Yachting on the Coast of Gdansk Pomerania (Poland). Études Caribéennes 2017. [CrossRef]

54. Kizielewicz, J.; Luković, T. The Phenomenon of the Marina Development to Support the European Model of Economic Development. TransNav 2013, 7. [CrossRef]

55. Zieziula, J.; Nowaczyk, P. Role of sail tourism in local economic development exemplified by Darłowo gmina of Darłowo. Ekon. Probl. Tur. 2018, 42, 241-249. [CrossRef]

56. Schlüter, M.; Lindkvist, E.; Basurto, X. The Interplay between Top-down Interventions and Bottom-up Self-Organization Shapes Opportunities for Transforming Self-Governance in Small-Scale Fisheries. Mar. Policy 2021, 128, 104485. [CrossRef]

57. Flannery, W.; Healy, N.; Luna, M. Exclusion and Non-Participation in Marine Spatial Planning. Mar. Policy 2018, 88, 32-40. [CrossRef]

58. Korinth, B.; Ranasinghe, R. Covid-19 Pandemic's Impact on Tourism in Poland in March 2020. GTG 2020, 31, 987-990. [CrossRef]

59. Uğur, N.G.; Akbıyık, A. Impacts of COVID-19 on Global Tourism Industry: A Cross-Regional Comparison. Tour. Manag. Perspect. 2020, 36, 100744. [CrossRef]

60. Więckowski, M. Will the Consequences of Covid-19 Trigger a Redefining of the Role of Transport in the Development of Sustainable Tourism? Sustainability 2021, 13, 1887. [CrossRef] 